\title{
PROGRAM PENGUATAN PENGETAHUAN DAN SIKAP SISWA TERHADAP PENGAMALAN NILAI-NILAI PANCASILA KOMUNITAS ROHANI ISLAM DI KOTA PANGKALPINANG
}

\author{
Musa $^{1)}$, Dinar Pratama ${ }^{2)}$ \\ IAIN Syaikh Abdurrahman Siddik Bangka Belitung \\ email: musaradit@gmail.com ${ }^{1)}$,dinarpratama24@gmail.com²)
}

\begin{abstract}
Abstrak
Program ini bertujuan untuk memberikan penguatan pengetahuan dan sikap nilai-nilai pancasila kepada Komunitas Rohani Islam siswa SMK Negeri Di Kota Pangkalpinang melalui pendampingan. Metode pendampingan melalui metode yang dikembangkan oleh Oos M. Anwas yang terdiri dari pemetaan komunitas, intervensi, dan evaluasi. Teknik pengumpulan data melalui kuesioner dan tes. Hasil analisis data menunjukkan bahwa, pengetahuan nilai-nilai pancasila siswa sebesar 69.7 pada pre test dan 75.3 pada post test. Sehingga terdapat peningkatan pengetahuan siswa setelah dilakukan kegiatan pendampingan sebesar 8 persen. Sikap siswa terhadap pengamalan nilai-nilai pancasila pada pre test sebesar 3.81 dan post test sebesar 4.00. Hasil uji beda nilai pre test dan post test mengenai sikap siswa terhadap pengamalan nilai-nilai pancasila menunjukkan nilai yang signifikan. Hal ini berarti terdapat perubahan sikap siswa setelah dilakukan pendampingan.
\end{abstract}

Kata Kunci: pengetahuan, sikap, nilai pancasila, komunitas rohani Islam.

\begin{abstract}
The programs aim to provide strengthening knowledge and attitude of national insight to the Islamic spiritual community students of Vocational High School in Pangkalpinang City through mentoring. Methods of mentoring through methods developed by Oos M. Anwas consisting of, community mapping, intervention, and evaluation. Data collection techniques through questionnaires and tests. The results of data analysis showed that the knowledge of the values of Pancasila students was 69.7 on the pre-test and 75.3 on the post-test. So, there is an increase in student knowledge after a mentoring activity of 8 percent. Student attitudes towards the practice of the values of Pancasila in the pre-test of 3.81 and post-test of 4.00. The test result of different pretest scores and post-tests on the students 'attitudes towards the practice of Pancasila values show significant value. This means that there is a change in students 'attitudes after mentoring.
\end{abstract}

Keywords: knowledge, attitudes, national insight, Islamic spiritual community.

\section{PENDAHULUAN}

Menurut Widiyantoro, (2003) Rohani Islam (ROHIS) dibentuk sebagai wadah siswa untuk dakwah di sekolah. ROHIS dibentuk dalam rangka melengkapi kekurangan jam pelajaran agama (Islam) sekaligus sebagai wadah yang dapat mengisi ruang kosong bagi pendidikan keagamaan siswa pasca Taman Pendidikan Al-Qur'an (TPA) Sehingga ROHIS seringkali berada pada jenjang pendidikan Sekolah Menengah Pertama dan Sekolah Menengah Atas sederajat.

Begitu juga di Kota Pangkalpinang, hampir tidak ada jenjang pendidikan SMP/MTs dan SMA/SMK/MA yang tidak memiliki ROHIS.
Terkhusus pada jenjan Sekolah Menengah Kejuruan (SMK) eksistensi lebih menonjol di banding jenjang pendidikan yang sederajat. SMK Negeri di Pangkalpinang berjumlah 5 sekolah, terdiri dari SMKN 1 dengan konsentrasi Akuntasi dan perkantoran, SMKN 2 konsentrasi teknik, otomotif, dan multimedia, SMKN 3 konsentrasi pariwisata, SMKN 4 konsentrasi pelayaran dan perikanan, dan SMKN 5 konsentrasi farmasi. Semuanya memiliki ROHIS dan beragam kegiatan keislamannya yang diposisikan sebagai kegiatan ekstrakurikuler. Kecuali, SMKN 2 Pangkalpinang, kegiatan ROHIS bersifat ekstrakurikuler bagi kelas 
XI dan XII dan intrakurikuler wajib bagi siswa kelas X (Susilawani, 2018)

ROHIS SMKN 2 dalam kurun waktu 2 tahun terakhir terkesan lebih menonjol dibandingkan ROHIS sekolah lainnya di Pangkalpinang. Hal ini karena ragam kegiatannya yang variatif juga didukung ekspose kegiatan di media massa. Kegiatan ROHIS SMKN 2 antara lain: Kajian Mingguan, Kajian Bulanan, Tilawah, Doa dan Zikir, Kajian Keislaman, Rihlah, Outbond, kerja bhakti di Masjid, dan tahfidz. Kegiatan-kegiatan ini tidak jarang dilaksanakan bersama dengan ROHIS sekolah-sekolah lain, tidak hanya sesama SMKN. ROHIS SMKN 2 terbagi ROHIS laki-laki dan ROHIS perempuan (SMKN 2 Pangkalpinang, 2017)

ROHIS di SMKN terdiri dari ROHIS lakilaki (akhwan) dan perempuan (akhwat) dengan pengurus dan manajemen masing-masing yang biasanya di bawah binaan guru. Keberadaan ROHIS cukup mampu memberi pengayaan pemahaman keislaman anggotanya, di tengah kondisi keterbatasan ruang mempelajari Islam di sekolah umum. Setiap siswa diwajibkan mengikuti kegiatan ROHIS, baik bersifat intra maupun ekstrakurikuler. Sehingga bisa dipastikan jika pemahaman keislaman siswa lebih dipengaruhi oleh kegiatan ROHIS daripada mata pelajaran agama 2 jam per minggu.

Kisaran tahun 1980, pada mula ROHIS mulai tumbuh dan berkembang, keberadaan organisasi ini hampir tidak menjadi perhatian, pihak Sekolah malah merasa terbantu dengan adanya kegiatan-kegiatan yang diselenggarakan. setelah berbagai riset menunjukan jika komunitas ini malah kontraproduktif dengan semangat kebangsaan Indonesia, barulah komunitas ini menjadi perhatian banyak pihak.

Kegiatan-kegiatan mereka selama ini menyentuh semua aspek dalam Islam seperti hablum min Allah, hablum min annas, dan hablum min alam; membaca al-qur'an, tata cara sholat, wirid dan zikir, tata cara berpakaian, dan berbagai persoalan Islam kontemporer lainnya; seperti pacaran dalam Islam dan lain-lain. Namun belum banyak membahas bagaimana hubungan Islam dalam kehidupan berbangsa dan bernegara (Pancasila, UUD 1945, NKRI, dan Bhineka tunggal Ika) secara lebih mendalam dengan narasumber yang memiliki kompetensi di bidang nilai-nilai pancasila dan Islam.

Bahkan tidak jarang, kegiatan ROHIS menjadi wadah membahas persoalan hubungan Islam dan NKRI yang viral di media sosial, melalui pertanyaan disampaikan peserta dan direspon seadanya oleh pengasuh. Sehingga tidak menuntup kemungkinan hal semacam inilah yang menimbulkan distorsi pemahaman anggota ROHIS tentang hubungan Islam dan negara di Indonesia sebagaimana banyak dipotret lembaga survei.

Pemilihan komunitas ROHIS SMKN di

Kota Pangkalpinang didasarkan pada pertimbangan; pertama, keberadaan ROHIS yang dalam pelaksanaan kegiatannya sepenuhnya dilakukan oleh pembina ROHIS yang ditunjuk sekolah, yang pada umumnya mereka adalah guru agama di sekolah yang bersangkutan tanpa ada kontrol terkait substansi program dan kegiatan dari sekolah. Kondisi ini memberi ruang yang luas bagi pembina untuk memberikan muatan atas nama "kemauan sendiri" dalam program dan kegiatan ROHIS.

Kedua, berdasarkan Survei Forum Koordinasi Pencegahan Terorisme (FKPT) Provinsi Kepulauan Bangka Belitung (FKPT, 2017) tahun 2017 mengenai "Sikap Siswa SLTA di Bangka terhadap Pencegahan Radikalisme", menunjukkan menguatnya entitas keagamaan siswa SLTA di Pulau Bangka (dengan responden juga ada berasal dari siswa SMKN Kota Pangkalpinang). Survei tersebut menunjukan $68,5 \%$ dari 35 siswa setuju membantu umat Islam di daerah konflik bersenjata dan setuju menerapkan hukum agama dalam kehidupan sehari-hari sebesar $74,3 \%$.

Hasil survei tersebut setidaknya menjadi gambaran umum mengenai sikap siswa di Bangka terhadap isu Islam dan kebangsaan. Jika dilihat dari angka survei tersebut, ada potensi pemahaman "radikal" yang dimiliki oleh siswa di Bangka. Siswa di Bangka perlu mendapat bimbingan dari mentor yang memiliki wawasan keIslaman yang moderat. Terutama di komunitas ROHIS yang biasanya rentan disusupi oleh mentor yang berpaham kurang moderat. Melalui pendampingan komunitas ROHIS ini siswa diberikan penguatan 
terutama dalam hal hubungan Islam dan Kebangsaan. Pemahaman dan sikap siswa diarahkan pada sikap yang lebih moderat dalam memandang perbedaan pemahaman kehidupan berbangsa dan beragama.

Kajian mengenai pemberdayaan masyarakat umumnya dilakukan pada suatu kelompok masyarakat atau komunitas tertentu. Pemberdayaan masyarakat selalu identik dengan upaya mendorong perubahan kearah yang lebih baik dalam kelompok masyarakat tertentu. Menurut Hatu, (2010), secara konseptual pemberdayaan (empowerment) berasal dari kata "power" yang berarti kekuasaan atau keberdayaan. Sehingga konotasi kekuasaan seringkali dikaitkan dengan kemampuan untuk membuat orang lain melakukan apa yang kita inginkan.

Sulistiani dalam Widjajanti, (2011) mengungkapkan bahwa, secara etimologis pemberdayaan berasal dari kata dasar "daya" yang berarti kekuatan atau kemampuan. Bertolak dari pengertian tersebut, maka pemberdayaan dimaknai sebagai proses untuk memperoleh daya, kekuatan atau kemampuan, dan atau proses pemberian daya, kekuatan atau kemampuan dari pihak yang memiliki daya kepada pihak yang kurang atau belum berdaya. Sumodiningrat sebagaimana yang dikutip Hatu, (2010) memberikan defenisi pemberdayaan sebagai upaya untuk memandirikan masyarakat lewat perwujudan potensi kemampuan yang mereka miliki.

Dalam beberapa literatur mengenai pemberdayaan masyarakat, manusia merupakan subjek pemberdayaan. AlFatih, (2010) mendefenisikan pemberdayaan sebagai rangkaian usaha yang dilakukan dalam rangka peningkatan kemampuan atau kemandirian masyarakat sehingga mereka dapat melakukan hal-hal yang produktif terhadap lingkungannya. Menurut Eko sebagaimana yang dikutip Cholisin, (2011) pemberdayaan merupakan proses mengembangkan, memandirikan, menswadayakan, memperkuat posisi tawar masyarakat kelas bawah terhadap adanya kekuatan penekan di berbagai bidang dan sektor kehidupan. Di lain hal, dalam memahami konsep pemberdayaan masyarakat dapat dilihat dari dua pendekatan sebagaimana yang diungkapkan
Widayanti, (2012) yakni, pendekatan developmentalisme dan pendekatan antidevelopmentalisme.

Pendekatan developmentalisme menganggap bahwa akar persoalan yang dihadapi manusia pada dasarnya bersumber dari ketidakberdayaan manusia itu sendiri. Pendekatan developmentalisme lebih dalam hal pemberdayaan masyarakat lebih menekankan pada konsep bottom up, bukan top down yang biasa digunakan oleh pemerintah dalam konsep pembangunan nasional. Pola top down cenderung membuat masyarakat lebih pasif tanpa mau berbuat apa-apa. Masyarakat terkadang menjadi sasaran program ataupun kebijakan yang bersifat pragmatis. Sehingga konsep pemberdayaan menurut pendekatan ini adalah upaya mengubah masyarakat yang sebelumnya adalah "korban" pembangunan menjadi "pelaku" pembangunan.

Pendekatan anti-developmentalisme merupakan kritik terhadap pandangan developmentalisme yang menganggap bahwa modernisasi dan developmentalisme adalah bungkus baru dari kapitalisme (Widayanti, 2012). Kritik terhadap pendekatan developmentalisme bukan hanya pada aras metodologi dan pendekatan, akan tetapi terhadap konsep dan diskursus pembangunan. Sehingga pandangan antidevelopmentalisme menjelaskan bahwa pemberdayaan merupakan upaya pembebasan dari determinisme dan atau kekuasaan yang absolut atas dasar aktualisasi dan koaktualisasi keberadaan manusia dan kemanusiaan yang beradab dalam sistem sosial, ekonomi, dan budaya.

Pendekatan lain terlait dengan upaya pemberdayaan masyarakat (empowering) dapat dikaji dalam tiga aspek sebagaimana yang diungkapkan Friedmann dalam Noor, (2011) yaitu, aspek enabling, aspek empowering, dan aspek protecting. Aspek enabling merupakan upaya untuk membangun suasana yang berpotensi masyarakat dapat berkembang. Asumsi aspek ini lebih memandang masyarakat sebagai subjek, bukan objek. Masyarakat dipandang sebagai subjek yang memiliki potensi, bukan sebagai objek yang tidak berdaya. Sehingga, pemberdayaan masyarakat lebih fokus pada upaya membangun kesadaran akan potensi yang mereka miliki. 
Aspek kedua dalam pemberdayaan masyarakat adalah empowering, yaitu upaya memperkuat potensi yang dimiliki masyarakat melalui usaha nyata atau kongkrit agar lebih berdaya. Lebih lanjut, Noor, (2011) menjelaskan upaya yang paling penting pada aspek empowering ini adalah meningkatkan taraf pendidikan, kesehatan, dan menyediakan akses-akses atau sumber informasi yang berkaitan dengan peningkatan kapasitas masyarakat. Aspek ketiga protecting, yaitu upaya melindungi dan membela masyarakat yang lemah. Perlindungan terhadap masyarakat yang lemah dalam konteks ini adalah masyarakat yang memiliki kapasitas dan kapabilitas rendah. Misalnya, kelompok masyarakat yang memiliki tingkat pendidikan rendah akan rentan dimanfaatkan oleh pihak luar. Oleh karena itu, masyarakat dengan kondisi seperti ini perlu mendapat pendampingan dan pemberdayaan.

Dampak positif pemberdayaan masyarakat selain dapat membangun kemandirian masyarakat, dalam jangka panjang juga dapat mensejahterahkan. Sebagaimana yang diungkapkan Moeljarto dalam Muslim, (2007) dalam upaya mensejahterahkan rakyat, terdapat setidaknya tiga model pembangunan yang pernah dilakukan oleh Indonesia. Pertama, model pembangunan nasional yang berorientasi pada pertumbuhan ekonomi. Kedua, model yang berorientasi pada kebutuhan dasar, dan ketiga, model yang berorientasi pada pembangunan manusia (people centered) Jika dilihat dari model tersebut, upaya pembangunan nasional yang lebih efektif melalui model people centered. Model ini tidak hanya fokus pada upaya peningkatan ekonomi dan pendapatan nasional, tetapi lebih jauh dari itu. Model ini menekankan pada upaya membangun kualitas manusia itu sendiri untuk meningkatkan partisipasi mereka secara nyata (Muslim, 2007).

Berdasarkan pengertian pemberdayaan sebagaimana yang diungkapkan di atas, maka dapat dipahami bahwa pemberdayaan merupakan upaya atau usaha untuk mendorong masyarakat agar dapat memahami potensi dirinya dan memberikan keterampilan agar mereka dapat berpartisipasi dalam pembenagunan masyarakat.
Penguatan nilai-nilai pancasila di kalangan komunitas ROHIS dilakukan dalam bentuk pendampingan. Dalam hal ini pendampingan dimaksudkan sebagai salah satu metode dalam pemberdayaan masyarakat yaitu komunitas ROHIS. Menurut Graha, (2009) terdapat lima kegiatan penting dalam pendampingan sosial yakni, 1) motivasi, 2) peningkatan kesadaran dan pelatihan kemampuan, 3) manajemen diri, 4) mobilisasi sumber, 5) pembangunan dan pengembangan jaringan.

Terkait dengan upaya penguatan nilai-nilai pancasila melalui pendampingan pada komunitas ROHIS SMK Negeri Se-Kota Pangkalpinang, konsep pemberdayaan sangat relevan untuk dapat memberikan pedoman dalam pelaksanaanya. Pendampingan menurut Rahayu \& Firmansyah, (2018) merupakan kegiatan yang dilakukan seseorang yang bersifat konsultatif, interaktif, komunikatif, motivatif, dan negosiatif.

Lebih lanjut Rahayu dan Firmansyah menjelaskan bahwa yang dimaksud dengan konsultatif yaitu, membangun kondisi dimana pendamping maupun yang didampingi bisa berkonsultasi dalam memecahkan masalah bersama-sama, interaktif artinya antara pendamping dan yang didampingi harus samasama aktif, komunikatif maksudnya adalah apa yang disampaikan pendamping atau yang didampingi dapat dipahami bersama, motivatif berarti pendamping harus bisa membangun kepercayaan diri dan sehingga dapat memberikan motivasi, dan negosiasi di sini berarti pendamping dan yang didampingi mudah melakukan penyesuaian (Rahayu \& Firmansyah, 2018)

Selain itu, hal penting lainnya terkait dengan strategi pendampingan komunitas adalah memperhatikan lingkungan. Teori ekologi Urie Brofenbrener dalam Santrock sebagaimana yang dikutip Yumpi, (2013) menjelaskan konteks perkembangan sosial dalam sistem lingkungan yaitu: 1) mikrosistem, merupakan tempat dimana individu hidup seperti keluarga, teman sebaya, di sekolah, tempat kerja, dan lain sebagainya. 2) Mesosistem, merupakan hubungan antar berbagai mikrisistem seperti hubungan antara keluarga dengan sekolah atau teman sebaya. 3) Ekosistem, merupakan pengaruh dari tempat lain yang tidak 
dialami secara langsung oleh individu seperti pengalaman atau pendidikan orang tua dapat mempengaruhi pola pengasuhan anaknya. 4) Makrosistem, merupakan budaya yang berkembang di lingkungan individu seperti etnis atau suku. 5) Kronosistem, merupakan kondisi dimana individu menghadapi situasi yang tidak mendukung kehidupan sosial seperti perceraian orang tua ataupun kondisi kemiskinan keluarga.

Jika merujuk pada teori ekologi di atas, pendampingan komunitas perlu memberikan porsi yang penuh pada faktor lingkungan. Karena bagaimanapun baiknya strategi dan model pendampingan yang dilakukan jika tidak dapat memahami lingkungan individu maka dampak dari pendampingan tersebut tidak akan konsisten. Perubahan individu akan sulit tercapai karena pada dasarnya mereka akan kembali kepada lingkungannya. Lebih lanjut, Childhope Asia dalam Yumpi, (2013) menegaskan bahwa pendekatan berbasis komunitas merupakan upaya pencegahan dan penanganan. Proses pendekatan berbasis komunitas lebih banyak berlangsung pada lingkungan keluarga yang sangat memungkinkan untuk menciptakan perubahan (Yumpi, 2013)

Dalam konteks pendampingan komunitas ROHIS, hal utama yang diharapkan adalah adanya perubahan individu dan kelompok. Perubahan tersebut setidaknya menyentuh pada ranah pengetahuan dan sikap. Terkait dengan hal ini, salah satu teori yang dapat dijadikan pedoman untuk memahami perubahan sosial sebagaimana yang diungkapkan Soekanto dalam Simmau, (2016) setidaknya terdapat beberapa faktor yang mendorong terjadinya perubahan tersebut yaitu, a) adanya singgungan atau kontak dengan budaya lain, b) sistem pendidikan, c) sikap menerima atau toleran terhadap penyimpangan, d) sikap terbuka masyarakat, e) kondisi masyarakat yang beragam, f) adanya sikap tidak puas masyarakat terhadap hal-hal tertentu, g) berorientasi pada masa depan, h) terdapat keyakinan bahwa manusia mestinya senantiasa berusaha untuk dapat memperbaiki atau meningkatkan taraf hidupnya.

\section{METODOLOGI PENGABDIAN}

Pendampingan dilakukan melalui tahapan, pemetaan, intervensi, dan evaluasi yang dikembangkan Oos, (2013). Sepanjang kegiatan Tim Pendamping senantiasa mencatat dan melaporkan bertujuan memberikan penguatan nilai-nilai pancasila dengan memberikan materi nilai-nilai pancasila dan keislaman, games penguatan nilai-nilai pancasila.

Teknik pengumpulan data dalam pendampingan ini menggunakan teknik kuesioner dan Tes. Instrumen tes digunakan untuk mengukur pemahaman materi yang diterima oleh peserta pada saat sebelum dan sesudah penyampaian materi. Instrumen angket/kuesioner digunakan untuk megetahui sikap terhadap nilai-nilai pancasila siswa sebelum dan sesudah pelaksanaan pendampingan.

\section{PELAKSANAAN KEGIATAN}

Kegiatan pendampingan diikuti sebanyak 30 perwakilan siswa ROHIS SMK se Kota Pangkalpinang. Adapun tahapan pendampingan diuraikan melalui kegiatan sebagai berikut:

Pertama, pemetaan keberadaan komunitas ROHIS dalam penguatan nilai-nilai pancasila para siswa dilakukan dengan brainstorming secara partisipatif dengan pegurus ROHIS. Dalam tahapan ini pengurus diminta mengevaluasi diri dengan menulis dan memaparkan apa saja kegiatan yang dilakukan selama ini dalam ROHIS sekolahnya masing-masing dalam kaitannya dengan penguatan pengetahuan nilai-nilai pancasila; meliputi kekuatan, kelemahan dan, peluang dan ancaman yang dimiliki. Tahapan ini, diakhiri dengan penentuan rencana tindak lanjut bagi penguatan pengetahuan nilai-nilai pancasila siswa.

Kedua, Tahap intervensi, merupakan tahapan pelaksanaan tindaklanjut yang sudah disusun pengurus ROHIS pada tahapan sebelumnya. Intervensi ini diberikan dalam bentuk penyampaian materi dan dialog, pemberian permainan (games), dan simulasi permainan peran guna memperkuat nilai-nilai pancasila siswa terhimpun dalam komunitas ROHIS.

Dalam intervensi, pendampingan akan melibatkan akademisi, tokoh agama, pengurus ormas Islam mainstream di Indonesia, yang memiliki pemikiran dan nilai-nilai pancasila yang tidak pernah diindikasi sebagi simpatisan terhadap kelompok-kelompok yang menentang pemerintah, simpatisan HTI dan ormas terlarang lainnya. Intervensi penguatam nilai-nilai pancasila siswa SMKN melalui komunitas ROHIS dalam bentuk penyampaian materi: Pemikiran Politik dalam Islam; Sejarah konsep negara (khilafah) dan perkembangannya dalam Islam; Nilai-nilai Islam 
dalam Pancasila; Konsep Jihad dalam Islam; Demokrasi dalam Islam dan pancasila; Kepemimpinan dalam Islam dan Pancasila; Gender dalam Islam dan Pancasila; Bendera, lagu Kebangsaan dalam Islam dan Pancasila; Games Penguatan Nilai-nilai pancasila 1, dan Games Penguatan Nilai-nilai pancasila

Ketiga, tahap evaluasi, evaluasi dilakukan dalam setiap tahapan, terutama terkait dengan penguatan nilai-nilai pancasila baik secara tertulis maupun lisan dengan melihat respon yang diberikan teradap pertanyaan dan pemaparan kasus.

Sepanjang kegiatan Tim Pendamping senantiasa mencatat dan melaporkan bertujuan memberikan penguatan nilai-nilai pancasila dengan memberikan materi nilai-nilai pancasila dan keislaman, games penguatan nilai-nilai pancasila.

\section{HASIL DAN PEMBAHASAN}

\section{Pengetahuan Mengenai Nilai-Nilai Pancasila}

Untuk mengetahui gambaran mengenai pengetahuan nilai-nilai pancasila maka terlebih dahulu peserta diberikan pre test. Dari 30 orang peserta yang mengikuti kegiatan penguatan nilainilai pancasila pada hasil pre test menunjukkan skor rata-rata sebesar 69.4 pada rentang 10-100. Hasil pre test pengetahuan nilai-nilai pancasila secara lengkap dapat dilihat pada tabel dan gambar histogram di bawah ini;

Tabel. 1. Skor Pre Test Pengetahuan Nilai-Nilai Pancasila

\begin{tabular}{llc}
\hline $\mathrm{N}$ & Valid & 30 \\
& Missing & 0 \\
\hline Mean & 69.70 \\
Median & 70.00 \\
Mode & $70^{\mathrm{a}}$ \\
Std. Deviation & 6.081 \\
\hline
\end{tabular}

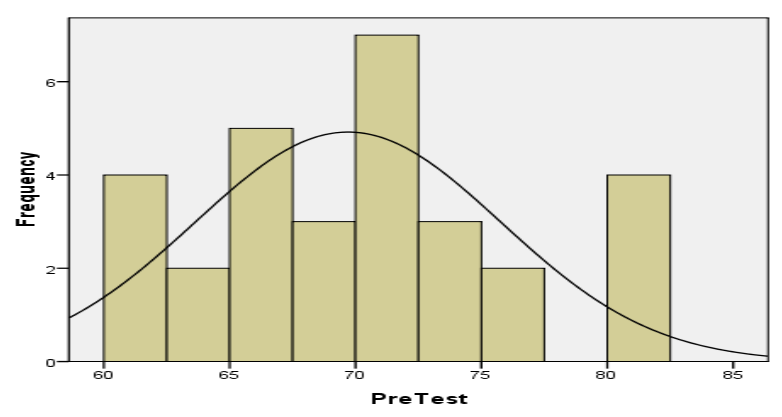

\section{Gambar 1. Histogram Skor Pre Test Pengetahuan Nilai-Nilai Pancasila}

Data deskriptif di atas menunjukkan bahwa, pengetahuan peserta mengenai pengamalan nilai-nilai pancasila masih tergolong rendah yaitu sebesar 69.4 persen. Pengetahuan yang masih relatif rendah ini menjadi dasar untuk melakukan penguatan melalui penyampaian materi - materi yang terkait dengan pengamalan nilai-nilai pancasila. Penyampaian materi dilakukan secara interaktif dengan mendorong para peserta untuk berdiskusi dan menyampaikan pendapatnya.

Adapun cakupan materi pengamalan nilainilai pancasila terdiri dari, 1) membangun toleransi antar umat beragama, 2) pancasila dan Islam perspektif kehidupan beragama, dan 3) pencegahan radikalisme di kalangan siswa. Strategi penyampaian materi dilakukan dengan tahapan sebagai berikut yakni, 1) bertanya, 2) diskusi, 3) refleksi. Strategi ini dilakukan dengan tujuan agar peserta ikut berperan aktif selama proses penyampaian materi.

Pada tahap awal peserta distimulasi sebuah kasus terkait dengan penyimpangan pemahaman yang rendah terhadap nilai-nilai pancasila. Dengan melihat kasus tersebut, diharapkan para peserta dapat mengajukan pertanyaan ataupun tanggapannya. Hal ini dilakukan untuk mengetahui pendapat awal para peserta sebelum penyampaian materi. Setelah peserta mengajukan pertanyaan atau menyampaikan pendapatnya maka, narasumber memberikan penjelasan dan tanggapan. Pada tahapan ini, tidak ditemukan pendapat peserta yang berpotensi melakukan penyimpangan dalam pengamalan nilai-nilai pancasila ataupun pemahaman Islam radikal.

Tahapan kedua yaitu diskusi. Diskusi dilakukan dengan membagi peserta menjadi tiga kelompk untuk membahas kasus diajukan di awal. Selama proses diskusi berlangsung, para peserta terus dipantau oleh narasumber dalam menyusun argumentasi. Setelah peserta diskusi, perwakilan dari setiap kelompok menyampaikan hasil diskusinya. Peserta salaing mengemukakan pendapatnya dan saling mengajukan pertanyaan kepada kelompok lain. Sesekali narasumber memberikan penguatan setelah peserta memberikan pendapat mereka mengenai suatu hal. Selama jalannya diskusi juga tidak ditemukan pendapat peserta yang memiliki pemahaman menyimpang.

Tahapan ketiga yakni, refleksi. Pada tahap ini, peserta dan narasumber melakukan refleksi terhadap jalannya penyampaian materi. Setiap 
peserta diminta untuk menjelaskan kembali apa yang dapat dipahami selama proses penyampaian materi. Selain itu, untuk menguatkan sikap peserta terhadap pengamalan nilai-nilai pancasila setiap peserta juga diminta untuk menyampaikan pendapatnya. Setelah mereka menyampaikan pendapatnya, kemudian narasumber akan menanyakan kembali bagaimana sikap yang seharusnya dilakukan oleh peserta terkait dengan pendapat yang disampaikan oleh peserta.

Setelah penyampaian materi selesai dilakukan, maka semua peserta diberikan soal post test pengamalan nilai-nilai pancasila. Tujuan post test ini adalah untuk melihat apakah ada peningkatan pengatahuan peserta setelah dilakukan proses penguatan pemahaman nilai-nilai pancasila. Berikut ini disajikan deskripsi hasil post test melalui tabel dan gambar histogram.

Tabel. 2. Skor Post Test Pengetahuan Nilai-Nilai Pancasila

\begin{tabular}{lrr}
\hline$N$ & Valid & 30 \\
& Missing & 0 \\
\hline Mean & & 75.73 \\
Median & 75.50 \\
Mode & $75^{\mathrm{a}}$ \\
Std. Deviation & 3.750 \\
\hline
\end{tabular}

Berdasarkan tabel 2 didapat skor rata-rata (mean) peserta sebesar 75.7 persen dengan standar deviasi sebesar 3.7. Jika dilihat dari skor rata-rata post test, pengetahuan peserta mengenai pengamalan nilai-nilai pancasila mengalami peningkatan sebesar 8 persen. Untuk memastikan apakah terdapat peningkatan yang signifikan berdasarkan metode statistika, maka dilakukan uji lanjut menggunakan $t$-test. Namun terlebih dahulu dilakukan uji persyaratan analisis yakni, uji normalitas data. Berikut ini hasil uji normalitas data menggunakan uji Liliefors melalui Software SPSS.16.

Tabel. 3. Hasil Uji Normalitas Data Skor Pre Test dan Post Test

\begin{tabular}{lccr}
\hline & \multicolumn{3}{c}{ Kolmogorov-Smirnov } \\
& Statistic & df & Sig. \\
\hline PreTest & .094 & 30 & $.200^{*}$ \\
PostTest & .099 & 30 & $.200^{*}$ \\
\hline
\end{tabular}

a. Lilliefors Significance Correction

Hasil uji normalitas melalui metode Liliefors didapat nilai signifikansi $0.200>0.05$ untuk data pre test dan post test. Karena nilai signifikansi lebih besar dari 0.05 maka data berdistribusi normal. Karena kedua data berdistribusi normal maka uji t atau $t$-test dapat dilakukan untuk melihat apakah peningkatan rata-rata pengetahuan nilainilai pancasila peserta signifikan. Hasil uji $\mathrm{t}$ menggunakan software SPSS.16 secara rinci dapat dilihat pada tabel di bawah ini;

Tabel. 4. Hasil Uji t Data Pre Test dan Post Test Pengetahuan Nilai-nilai Pancasila

Paired Differences

$95 \%$

Confidence

Std. Std. Interval of $t \quad$ Sig.

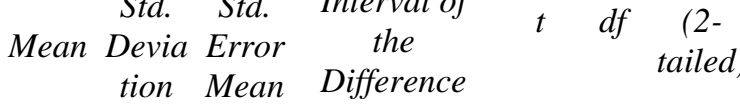

Lowe

\begin{tabular}{|c|c|c|c|c|c|c|}
\hline & & & $r$ & Upper & & \\
\hline 6.033 & 5.732 & 1.047 & $\begin{array}{c}- \\
8.174\end{array}$ & $\begin{array}{c}- \\
3.893\end{array}$ & ${ }_{5.765}^{-} 29$ & .000 \\
\hline
\end{tabular}

Berdasarkan hasil uji t, didapat nilai sig. (2tailed) sebesar $0.00<0.05$ sehingga signifikan. Sehingga dapat disimpulkan bahwa, terdapat peningkatan pengetahuan nilai-nilai pancasila peserta sebelum dan sesudah dilakukan penyampaian materi. Skor rata-rata sebelum diberikan materi sebesar 69.7 dan setelah diberikan penguatan materi sebesar 75.7. Jika di persentasekan maka ada peningkatan pengetahuan peserta terhadap materi nilai-nilai pancasila sebesar 8 persen.

\section{Sikap Siswa Terhadap Pengamalan Nilai-Nilai Pancasila}

Data mengenai sikap siswa ini diukur melalui kuesioner yang diisi oleh seluruh peserta yang berjumlah 30 orang. Pengisian kuesioner dilakukan sebanyak dua kali, yakni pada saat sebelum (Pre Test) dan sesudah (Post Test) pendampingan. Data ini disajikan dalam bentuk statistik deskriptif seperti, skor mean, median, mode, dan standar deviasi. Untuk mengetahui seberapa tinggi sikap siswa maka data digolongkan kedalam 5 kategori, sangat baik, baik, cukup, kurang baik, dan sangat tidak baik. Tabel 5 ini menunjukkan kategori data tersebut. 
Tabel. 5. Kategori Data Sikap Siswa

\begin{tabular}{cc}
\hline Kategori & Skor \\
\hline Sangat Tidak Baik & $\leq 2.42$ \\
Kurang Baik & $2.43-3.46$ \\
Cukup & $3.47-4.51$ \\
Baik & $4.52-5.56$ \\
Sangat Baik & $\geq 5.57$ \\
\hline
\end{tabular}

Berikut ini sajian data pre test sikap siswa terhadap pengamalan nilai-nilai pancasila.

Tabel. 6. Data Pre Test Sikap Siswa Terhadap Pengamalan Nilai-Nilai Pancasila

\begin{tabular}{lr}
\hline$N \quad$ Valid & 30 \\
$\quad$ Missing & 0 \\
\hline Mean & 3.81 \\
Median & 4.00 \\
Mode & 4.00 \\
Std. Deviation & 1.14 \\
\hline
\end{tabular}

Tabel 6 di atas menunjukkan rata-rata (mean) sebesar 3.81 dengan standar deviasi sebesar 1.14 pada skala 1-5 yang masuk pada kategori cukup. Secara deskriptif sikap siswa terhadap pengamalan nilai-nilai pancasila masuk pada kategori cukup.

Hasil pre test di atas kemudian dijadikan dasar untuk melakukan penguatan terkait dengan sikap terhadap pengamalan nilai-nilai pancasila. Setelah dilakukan penguatan kemudian dilanjutkan dengan mengukur sikap siswa setelah dilakukan penguatan melalui pengisian kuesioner. Berikut ini data hasil post test sikap siswa terhadap pengamalan nilai-nilai pancasila.

Tabel. 7. Data Post Test Sikap Siswa Terhadap Pengamalan Nilai-Nilai Pancasila

\begin{tabular}{lcc}
\hline$N$ & Valid & 30 \\
& Missing & 0 \\
\hline Mean & 4.00 \\
Median & 4.00 \\
Mode & 4.00 \\
Std. Deviation & 1.05 \\
\hline
\end{tabular}

Tabel 8 di atas menunjukkan rata-rata (mean) sebesar 4.00 dengan standar deviasi sebesar 1.05 pada skala 1-5 yang masuk pada kategori cukup. Secara deskriptif sikap siswa terhadap pengamalan nilai-nilai pancasila masuk pada kategori cukup.
Berdasarkan data pada tabel 9 di atas, sikap siswa untuk mengamalkan nilai-nilai pancasila paling tinggi pada aspek sila ke 1 sebesar 4.15 dan sila ke 3 sebesar 4.06 pada skala 1-5. Aspek terendah berada pada pengamalan pancasila sila ke 5 sebesar 3.85. Secara total sikap siswa terhadap pengamalan nilai-nilai pancasila sebesar 4.00 dengan kategori cukup. Untuk melihat perbandingan peningkatan sikap siswa terhadap pengamalan nilai-nilai pancasila dapat dilihat pada tabel di bawah ini:

Tabel. 8. Rekapitulasi Data Pre Test dan Post Test Sikap Siswa Terhadap Pengamalan Nilai-Nilai Pancasila

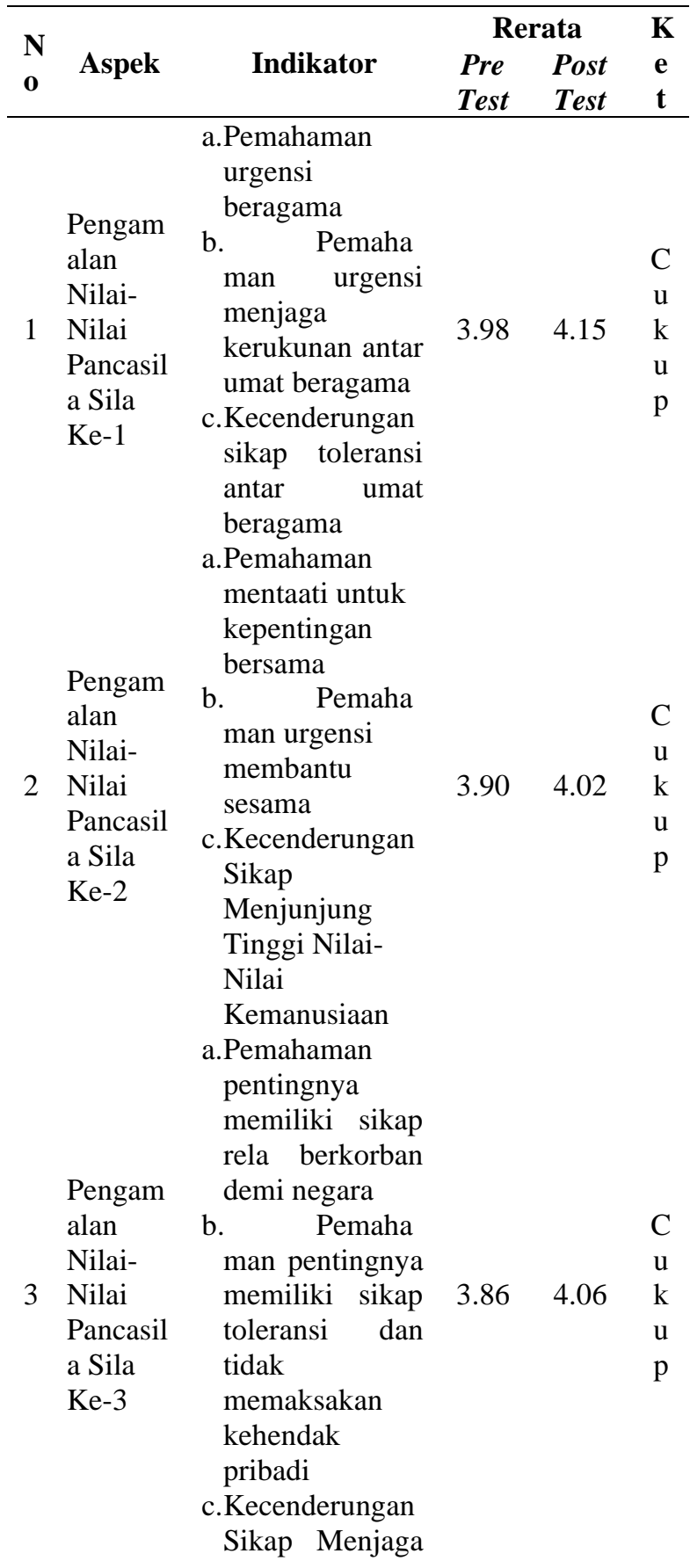




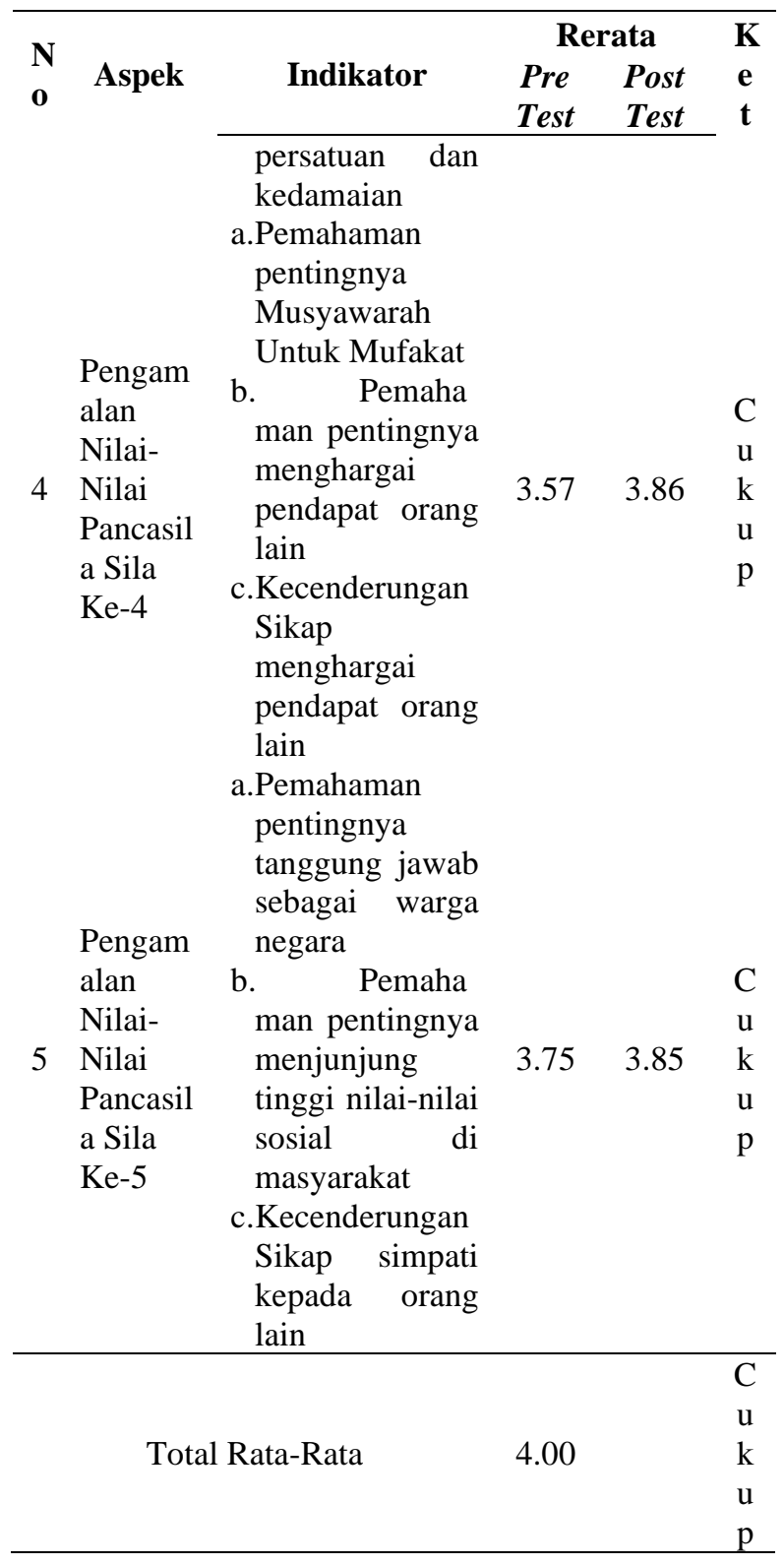

Rekapitulasi data post test sikap siswa terhadap pengamalan nilai-nilai pancasila di atas menunjukkan adanya peningkatan pada skor semua aspek. Untuk melihat berapa persetanse kenaikan pada setiap aspek dapat dilihat pada tabel 9 .

Berdasarkan tabel 9, secara keseluruhan peningkatan sikap siswa naik sebesar 3.03 persen. Untuk dapat menentukan apakah terdapat peningkatan yang signifikan maka dilakukan uji lanjut menggunakan metode $t$-test. Metode t-test digunakan untuk mengetahui keberartian perbedaan dua kelompok data. Dalam hal ini akan diuji apakah data hasil pengukuran sikap siswa sebelum dilakukan penguatan dengan data sikap siswa setelah dilakukan penguatan berbeda secara signifikan. Sebelum dilakukan uji t maka terlebih dahulu data yang akan diuji memiliki asumsi normalitas data. Pengujian normalitas data menggunakan metode Liliefors. Berikut ini tabel hasil uji normalitas data pre test dan post test sikap siswa terhadap pengamalan nilai-nilai pancasila.

Tabel. 9. Persentase Peningkatan Skor Sikap Terhadap

Pengamalan Nilai-nilai Pancasila

\begin{tabular}{|c|c|c|c|}
\hline Aspek & $\begin{array}{l}\text { Pre } \\
\text { Test }\end{array}$ & $\begin{array}{c}\text { Post } \\
\text { Test }\end{array}$ & Persentase \\
\hline $\begin{array}{l}\text { Pengamalan Nilai- } \\
\text { Nilai Pancasila Sila } \\
\text { Ke-1 }\end{array}$ & 3.98 & 4.15 & $3.19 \%$ \\
\hline $\begin{array}{l}\text { Pengamalan Nilai- } \\
\text { Nilai Pancasila Sila } \\
\text { Ke-2 }\end{array}$ & 3.9 & 4.02 & $3.05 \%$ \\
\hline $\begin{array}{l}\text { Pengamalan Nilai- } \\
\text { Nilai Pancasila Sila } \\
\text { Ke-3 }\end{array}$ & 3.86 & 4.06 & $3.11 \%$ \\
\hline $\begin{array}{l}\text { Pengamalan Nilai- } \\
\text { Nilai Pancasila Sila } \\
\text { Ke-4 }\end{array}$ & 3.57 & 3.86 & $2.94 \%$ \\
\hline $\begin{array}{l}\text { Pengamalan Nilai- } \\
\text { Nilai Pancasila Sila } \\
\text { Ke-5 }\end{array}$ & 3.75 & 3.85 & $2.88 \%$ \\
\hline Rerata Total & & $\begin{array}{c}3.03 \\
\%\end{array}$ & \\
\hline
\end{tabular}

Tabel. 10. Hasil Uji Normalitas Data Pre Test Dan Post Test Sikap Siswa Terhadap Pengamalan NilaiNilai Pancasila

\begin{tabular}{lcrc}
\hline & \multicolumn{4}{c}{ Kolmogorov-Smirnov } \\
& Statistic & Df & Sig. \\
\hline Pre Test & .219 & 5 & $\mathbf{. 2 0}^{*}$ \\
Post Test & .237 & 5 & $\mathbf{. 2 0}^{*}$
\end{tabular}

a. Lilliefors Significance Correction

Tabel. 11. Hasil Uji t Data Pre Test dan Post Test Sikap Siswa Terhadap Pengamalan Nilai-Nilai Pancasila

\begin{tabular}{|c|c|c|c|c|c|c|}
\hline \multicolumn{6}{|c|}{ Paired Differences } & \multirow{3}{*}{$\begin{array}{c}\text { Sig. } \\
(2- \\
\text { tailed) }\end{array}$} \\
\hline Mean & $\begin{array}{l}\text { Std. } \\
\text { Devia } \\
\text { tion }\end{array}$ & $\begin{array}{l}\text { Std. } \\
\text { Error } \\
\text { Mean }\end{array}$ & $\begin{array}{l}95 \% \\
\text { Confidence } \\
\text { Interval of the } \\
\text { Difference }\end{array}$ & $\mathrm{t}$ & & \\
\hline & & & Lower Upper & & & \\
\hline 17.600 & $\begin{array}{c}.0750 \\
3\end{array}$ & .03356 & ${ }^{-} .6917^{-.08283}$ & 5.245 & 4 & .006 \\
\hline
\end{tabular}

Hasil pengujian normalitas data didapat nilai Sig. $0.200>0.05$ maka data berdistribusi normal baik data pre test maupun data post test. Persyaratan analisis telah terpenuhi maka langkah 
selanjutnya adalah melakukan uji t untuk mengetahui signifikansi perbedaan pada kedua kelompok data. Hasil uji t dapat dilihat pada tabel 11.

Hasil uji t pada Tabel 11 menunjukkan bahwa, nilai sig. $0.006<0.05$ yang berarti terdapat perbedaan yang signifikan antara data pre test dan post test. Sehingga dapat disimpulkan bahwa, terdapat peningkatan sikap siswa terhadap pengamalan nilai-nilai pancasila sebelum dan sesudah dilakukannya penguatan dan pendampingan. Kegiatan pendampingan dalam rangka penguatan wawasan nilai-nilai pancasila khususnya bagi siswa ROHIS SMK Negeri di Kota Pangkalpinang didasari oleh adanya potensi pemaaman intoleran. Pemhaman intoleran jika terus dibiarkan akan berakibat pada keyakinan yang dianut siswa yang memandang perbedaan merupakan sebagai sesuat yang tidak dapat diterima atas dasar pemahaman mereka. Pendampingan yang dilakukan kepada siswa ROHIS SMK Negeri di Kota Pangkalpinang ini berjumlah 30 orang.

Berdasarkan hasil pengukuran terhadap 30 peserta pendampingan dalam hal pengetahuan siswa terhadap nilai-nilai pancasila terdapat peningkatan pemahaman. Pemahaman mengenai nilai-nilai pancasila penting dipahami oleh setiap generasi muda, bahkan semua rakyat Indonesia. Memahami nilai-nilai pancasila yang terkandung dalam Pancasila sebagai dasar dan ideologi Bangsa dapat membentuk rasa nasionalisme tinggi. Jika generasi kita memiliki nasionalisme tinggi maka mereka tidak mudah dipengaruhi oleh pemahaman ani nasionalisme.

Bangsa Indonesia sangat rentan terjadi perpecahan antar sesama (konflik horizontal) Umumnya isu SARA (Suku, Ras, dan Agama) menjadi penyebab utamanya. Akhir-akhir ini, muncul kelompok-kelompok yang mengatasnamakan agama yang berupaya untuk menggantikan ideologi Negara. Kelompok tersebut umumnya didoktrin dengan pemahaman agama yang sempit dalam memahami kehidupan beragama dan berbangsa. Mereka menganggap bahwa, jika ada sebagian masyarakat yang memiliki pemahaman berbeda maka dianggap salah.

Setidaknya melalui kegiatan pendampingan ini, siswa ROHIS khususnya yang merupakan wadah dalam memahami ilmu agama mendapat pemahaman agama yang selaras dengan pemahaman nilai-nilai pancasila. Sehingga, tidak ada pertentangan antara agama dengan Negara. Harmonisasi antara agama dan negera dapat saling melengkapi satu sama lain. Adapun persoalan perbedaan, baik dalam hal agama, suku, maupun ras sudah sangat jelas diatur dalam agama dan aturan Negara.

Selain melakukan penguatan pengetahuan dan pemahaman siswa mengenai hubungan agama dan Negara, pendampingan ini juga berupaya mengubah paradigma siswa untuk senantiasa bersikap moderat dan toleran. Hasil pengukuran sikap siswa terhadap pengamalan nilai-nilai pancasila menunjukkan peningkatan secara ratarata. Akan tetapi, peningkatan tersebut tidak berarti atau signifikan pada metode uji statistika. Walaupun secara statistik sikap siswa tidak mengalami peningkatan yang berarti, jika dilihat berdasarkan aspeknya terdapat peningkatan. Jika dipersentasekan, peningkatan sikap siswa secara keseluruhan aspek pengamalan nilai pancasila sebesar 3 persen. Angka tersebut menunjukkan bahwa, sikap siswa terhadap pengamalan nilai-nilai pancasila yang termaktub dalam pancasila masih masuk pada kategori cukup.

Walaupun demikian, pendampingan ini belumlah akhir dari upaya menguatkan pemahaman dan mendorong sikap siswa terhadap pengamalan nilai-nilai pancasila. Akan tetapi, kegiatan yang serupa perlu terus digalakkan agar siswa khususnya yang tergabung dalam komunitas keagamaan seperti ROHIS mendapat wadah dalam memahami agama dan Negara.

\section{PENUTUP \\ Kesimpulan}

Berdasarkan hasil penelitian dan pembahasan sebelumhya, pengetahuan nilai-nilai pancasila siswa komunitas ROHIS SMKN di Kota Pangkalpinang sebesar 69.70 pada pre test dan 75.3 pada post test. Terdapat peningkatan pengetahuan siswa setelah dilakukan kegiatan pendampingan sebesar 8 persen. Sikap siswa anggota Komunitas ROHIS SMKN di Kota Pangkalpinang terhadap pengamalan nilai-nilai pancasila pada pre test sebesar 3.81 dan post test sebesar 4.00. Hasil uji beda menunjukkan bahwa terdapat peningkatan sikap siswa terhadap pengamalan nilai-nilai pancasila setelah dilakukan pendampingan.

\section{Saran}

Berdasarkan kesimpulan di atas, maka dapat dirumuskan beberapa saran kepada pihakpihak yang berkepentingan sebagai berikut:

\section{Bagi Sekolah}

Sekolah hendaknya mulai melakukan kontrol terhadap aktivitas siswa yang 
tergabung dalam komunitas ROHIS dalam hal pemilihan Pembina maupun materinya.

2. Bagi Orang Tua

Orang tua perlu ikut serta dalam mendampingi anak-anak mereka terutama dalam hal pemahaman keagamaan dan Negara.

3. Bagi Pemerintah

Pemerintah dalam hal ini Dinas Pendidikan perlu membuat regulasi khusus mengenai pencegahan pemahaman sempit tentang agama dan Negara dan membuat program-program untuk memupuk nasionalisme siswa.

\section{DAFTAR PUSTAKA}

Cholisin. (2011). Pemberdayaan Masyarakat. Retrieved from http://staffnew.uny.ac.id/upload/131474282/ pengabdian/PEMBERDAYAAN+MASYAR AKAT.pdf

Fatih, A. Al. (2010). Implementasi Kebijakan dan Pemberdayaan Masyarakat: Kajian Pada Implementasi Program Kemitraan Dalam Rangka Memberdaya Usaha Kecil (W. N. Dkk, Ed.). Bandung.

FKPT Provinsi Kepulauan Bangka Belitung. (2017). Laporan Survei FKPT. Pangkalpinang.

Graha, A. N. (2009). Pengembangan Masyarakat Pembangunan Melalui Pendampingan Sosial dalam Konsep Pemberdayaan di Bidang Ekonomi. Jurnal Ekonomi Modernisasi, 5(2), 117-126.

Hatu, R. (2010). Pemberdayaan Dan Pendampingan Sosial Dalam Masyarakat (Suatu Kajian Teortis). Jurnal Inovasi, 7(04).

Munawar Noor. (2011). Pemberdayaan Masyarakat. Jurnal Ilmiah CIVIS, 1(2), 8799.

Muslim, A. (2007). Pendekatan Partisipatif Dalam Pemberdayaan Masyarakat. Jurnal Aplikasi Ilmu-Ilmu Agama, 8(2), 89-103.

Nugroho Widiyantoro. (2003). Panduan Dakwah
Sekolah, Kerja Besar Untuk Perubahan Besar. Bandung: Syaamil Cipta Media.

Oos, M. A. (2013). Pemberdayaan Masyarakat di Era Global. Bandung: Alvabeta.

Rahayu, G. D. S., \& Firmansyah, D. (2018). Pengembangan pembelajaran inovatif berbasis pendampingan bagi guru sekolah dasar. Abdimas Siliwangi: Jurnal Pengabdian Kepada Masyarakat, 1(1), 1725.

Simmau, S. (2016). Perubahan Sosial pada Komunitas Pemulung di TPAS Antang Tamangapa Kota Makassar. SOCIUS: Jurnal Sosiologi, 1(2), 64-70.

SMKN 2 Pangkalpinang. (2017). Poster Kegiatan ROHIS SMKN 2 Pangkalpinang. Pangkalpinang.

Susilawani. (n.d.). Wawancara Pribadi. Pangkalpinang, 20 September 2018.

Widayanti, S. (2012). Pemberdayaan Masyarakat: Pendekatan Teoritis. Jurnal Ilmu Kesejahteraan Sosial, 1(1), 87-102.

Widjajanti, K. (2011). Model pemberdayaan masyarakat. Jurnal Ekonomi Pembangunan: Kajian Masalah Ekonomi Dan Pembangunan, 12(1), 15-27.

Yumpi, F. (2013). Rekonstruksi Model Penanganan Anak Jalanan Melalui Pendampingan Psikologis, Suatu Intervensi Berbasis Komunitas. Jurnal Penelitian Psikologi, 4(2). 